\title{
Village Institution in Utilizing Village Funds in Namlea District
}

\author{
Tim Kerja PSP2M Uniqbu
}

\begin{abstract}
The Village fund is a government effort to support the development of the village through financing schemes that are regulated and implemented directly by the village government, the involvement of village institutions in the management of village funds into an institutional relationship that is able to Village Fund Management. This research is a qualitative study aimed to describe the relationship of village government with village institutions in the planning and implementation of development based on the allocation of village funds obtained. The research site is focused on Namlea subdistrict with the consideration of density and heterogeneity of society. The number of informant that will be interviewed as many as 40 people taken in purposive. The analytical techniques used follow the concept given Miles and Huberman. The results showed that the relationship that awakened has a positive impact on the planning, implementation and supervision of the use of the village funds with the presence of the engagement, the sense of having and responsibility to the management Village funds are not merely the responsibility of the villagers but rather to be a responsibility with the parties involved.
\end{abstract}

Keywords: Village, Relation, Village Funds, Namlea, Goverment

\section{INTRODUCTION}

Namlea subdistrict is the capital of Buru Regency consisting of 11 villages and 9 hamlets. The area of Namlea subdistrict is $226.55 \mathrm{~km}^{2}$ and has the highest number of inhabitants in Buru regency. Inhabitants of Namlea sub-district according to the data of Central Statistic Bureau year 2018 is 34,326 inhabitants. This number has increased steadily every year with a population growth rate of 6.26 percent (central Statistic agency, 2018)[1]. With this increase in population, it automatically leads to higher levels of population density which indicates that there are more problems that will arise in the midst of community life[2].

Pursuant to article 23 paragraph 1 of the constitution year 1945, funding for development and allocation of State budget (APBN) is always aimed at realizing the welfare of the people. In order to support the equitable development, the budget of 2014 has allocated the Regional Transfer Fund of Rp. 592.6 trillion or 32.2 percent against State expenditure[3].

In its development, people in the region, especially in rural areas, still face poverty, retardation and difficulties in accessing public services. This condition encourages awareness of the need to equalization development and public financial support (APBN) for the village community. The APBN allocation for the village is expected to attract community involvement in development.

Development at the village level has long been rolled out with the assistance of the Government of Bonat with the allocation of village funds taken from 10\% of APBD funds[4], since the issuance of enactment number 6 year 2014 about the village then Village development can be done With village funds.

From the total number of village funds, Buru Regency has a total of 65,863,399,000 village funds[5]. This is not a small amount if it is then distributed to the village in Buru Regency. However, according to Permendes's mandate, the village funds were prioritized to finance development spending and village community empowerment. With the village funds, each village must do the development of the village, especially in the field of development of local economic potential[6].

Tangkumahat in his research on the impact of the Village fund program in 2017 showed that the village fund Progam in Pineleng district went well enough, but in the future it is necessary to increase the capacity and expertise of the village government apparatus In order to support the implementation of this program to improve the economy and well-being of the community. In addition, a village head relation with the Village representative body (BPD) is needed to maintain the existence and optimization of Village Fund program. In addition, Daraba from the research results in the district of Galesong explained that the community participation was started since the preparation of the medium Term Development plan (RPJM), implementation of Village development, and utilizing the results of Village development. The Village fund Program is positively and significantly influential towards the participation rate of village people and the relationship between village stakeholders[7].

This research was conducted based on the preference of village head and BPD in Namlea Sub-district in implementing Village Fund program[8]. In addition, the research aims to obtain a primary picture of relationships that are awakened with logical consequences that impact the utilization of village funds in Namlea subdistrict.

\section{LITERATURE REVIEW}

\subsection{Village Goverment}

Governance is interpreted as a group of people who manage authority, perform leadership and coordination of government and community development from institutions where they are placed[9]. According to Syafiie Etymologically, the government can be interpreted as follows; (1) The commandment means to do the work. Which means that in them are two parties, namely the ruling having authority and which is ruled to have obedience will be imperative. (2) After adding the prefix "PE" to government. That means the body that performs the ruling power. (3) After the addition of "an" suffix to government. Means the deed, the way, the thing or the affairs of the Governing body[10].

Governance in a broad sense is all the affairs of the State in conducting the welfare of its people and the interests of its own countries, so it is not interpreted as a government that only conducts executive duties only, but also Includes other duties including legislative and judiciary. The village government according to Saparin in his book "Governance and Village government administration" stated that: "The village government is a formal symbol of the unity of the village community. The 
village government is supervised under the leadership of a village head and its officials (village device), representing the community of villages for the relationship to the outside and into the society concerned[11].

Village Government is the element of the village government, according Nurcholis (2011:138) The government has a basic task: (1) Implementing Village Household affairs, general government affairs, building and building communities. (2) to carry out assistance from governments, provincial governments and district governments. It is the function of the village government that directly relates to the social situation in community life.

According to Rivai the function of village government is social symptom, because it must be manifested in the interaction between individuals in the social situation of a community group[12]. The function of the village government operationally distinguishable in basic functions, namely as follows; (1) Instructive function, this function is one-way communication. The government as a communicator is the determining of what, how, when, and where the government is done so that the decision can be implemented effectively. (2) Consultative function, this function is used as two-way communication. It is used as an attempt to establish a decision that requires a material consideration and may need consultation with the community in the lead. (3) Function of participation, in carrying out this function The village government seeks to activate its society, both in the participation of the decision and in the implementation. Participation does not mean free to do so, but it is done in a controlled and directed form of cooperation by not interfere with or take on the basic tasks of others. (4) Delegate function, this function is executed by giving the delegation the authority of making or establishing either through approval or without government approval. This delegation function essentially means trust[13]. (5) Control function, control function assumes that effective leadership should be able to drive the activity of its members in a directional and deep. Effective coordination, making it possible to achieve the utmost goals together in carrying out the control function of the leader can make it happen through guidance, direction, coordination and supervision activities[14].

In a simple society though, in which case the goal is to be achieved is still simple and the need to be achieved is not complicated, cooperation with others has been perceived importance[15]. Meanwhile, the village government's understanding by local regulations on village government organizational guidelines, stating that the village government is the village head and village device. Village government is an element of village government organizing, according to government Nurcholis has a basic task; (1) To implement village household affairs, general government affairs, build and nurture communities. (2) to carry out assistance from governments, provincial governments and district governments[16]. From the main task is the function of village government that directly related to social situation in community life. The function of village government is social symptom, because it must be manifested in the interaction between individuals in the social situation of a community.

\subsection{Village Funds}

Village Development has a very important and strategic role in the framework of national development and regional development, because it contains elements of equitable development and its results and directly touching the interests of Most of the people living in rural areas in order to increase their wellbeing efforts. In the development of village government village domiciled as a subsystem of government administration system in Indonesia, so the village has the authority, duty and obligation to manage and manage the interests of its own community or Known for regional autonomy[17][18].

In organizing the authority, duties, and obligations of the village in the implementation of government and development, it takes village income source[19]. Responding to this, the government issued a policy of financial support which is the village fund which is the fund or DanDes sourced from the state expenditure budget allocated for villages transferred through the income budget Shopping district/city and used to finance government administration, implementation of development, community development, and public empowerment.

According to the Minister of Finance Regulation No. 49 year 2016 on how to manage[20], dispense, use, monitoring, and evaluation of village funds, village funds are funds sourced from the State budget and expenditure that is destined for the village Transferred through budget of the regional revenue and expenditure district/city and used to finance governance, implementation of development[21], community coaching[22], and community empowerment.

The APBN is a source of financing for village funds aimed at villages that can be transferred through regional budget and expenditure budgets (APBD) districts or cities and used in funding for governance, development, and empowerment of Mashallah Rakat. It is further stated that the village building seeks to improve the quality of life or increase the welfare of rural communities[23]. Community Empowerment is an effort to develop self-reliance and welfare through increased knowledge, behaviour, awareness, attitude, skills, ability, and utilization of resources by assigning activities, Programs, and policies, and mentoring that need to be adjusted to the essence of the problem and priority of the needs of the village community [24].

Village funds can be used for the development and empowerment of village communities[25]. The use of village funds is prioritized for Village development with its allocator to achieve Village development objectives, with improved welfare and quality of life and can overcome poverty by meeting basic needs, development Infrastructure, development of local economic and natural resources and sustainable management of the environment. The Program/activity is expected to be related to the aspect of Village development objectives[26].

Priority of utilization of village funds related to the development of village facilities and infrastructure based on the condition and potential in the village, as the target of RPJM and RKP Desa every year. Village fund whose source of funds comes from the state Budget in empowering rural communities to overcome poverty and increase access to economic resources. Regulation of the Minister of Finance number 49/2016 regulates the ordinances of allocation, distribution, use, monitoring, and evaluation[27]. It is explained that the administration, accounting, and financial reporting aspects are implemented in accordance with the provisions of the legislation. The expense of village APBD as a result of village expenditure requires the design in relation to village regulations discussing APBD village which is defined in the village regulations. Village heads should make a report to 
the regent each year end of the budget. To ensure accountability in the management of village finances, must be regulated by a variety of clear regulations[28][29].

Relations are a relationship between related institutions, to discuss village head relations and the village consultative Agency, this using executive and legislative relations in the presidential administration[30]. Indonesia is a country that adheres to the presidential government system, where the executive is the highest institution of the country that is not shared and elected directly by the people. The relationship between executives and legislatures is equivalent/partner[31].

Villages in the Namlea district between the village head and the village consultative agency have equivalent functions. The village chief is the executive institution in the village, and the BPD is a legislative institution in the village. The two have their own functions[32]. As an adherent to the presidential government system, between the executive and the legislature has no higher power the head of the village domiciled as the head of government in the village while the BPD is as the supervisory institution of government And also as a legislative institution that is involved in the making of the village regulation. The realization of the presidential government system then make the village should be able to perform the appropriate governmental functions, the head of the village and the BPD must jointly be able to perform the government functions that exist in the village with the aim to jointly Can realize the welfare of villagers.

\section{Method}

The research was conducted in Namlea subdistrict, Buru regency. Namlea subdistrict was chosen as the research location because the percentage of population population and aspect of high heterogeneity is compared with other sub-districts in Buru Regency. The number of informant that will be interviewed as many as 40 people taken in purposive[33] with consideration of respondents are considered as parties related to the research objectives[34]. The informant in this study consists of village apparatus, public figures, religious figures, youths and communities residing in Namlea subdistrict.

In the interview step researchers conducted a thorough interview with the related parties as well as provided a questionnaire to the informant at the location[35] in response to the involvement of village institutions and other supporting factors[36]. Researchers are also looking for complementary information[37] regarding the Village Fund program run by the government and the community in Namlea district through the Internet and the study of the library using the government Documents/archives associated with Policy for village funds. The analytical techniques used in this study are the analysis of qualitative data following the concepts given by Miles and Huberman and Spradley. Miles and Huberman, said that activities in the analysis of qualitative data are conducted interactively and ongoing continuously at every stage of research so that it is complete[38], its data until saturated. Activity in data analysis is data reduction, data presentation, conclusion withdrawal.

\section{RESULt}

The essence of development is the continuous process of change which is progress and improvement in the predetermined direction. "Development is a business or a series of business growth and planning changes that are made consciously by a nation, state and government to modernity in the framework of the nation's construction" (Siagian 1994). Development is a process of change in the better direction through a planned effort[39].

In the course of planning and implementation of Village development, the village government is accompanied by the District government/city which is technically implemented by the device unit of district/city. To coordinate Village development, village heads can be accompanied by professional escort personnel, village community Empowerment cadres, and or third parties[40]. Other designations will coordinate mentoring in the region. Village development includes the area of village governance, implementation of Village development, village community construction and Village Society empowerment.

For this, researchers interviewed GK informant who said that in a development planning there is generally must require analysis and identification that aims to parse the program that will be planned to fit Development needs in the village, therefore the village government spread in Namlea sub-district formed a special team consisting of village devices as well as community members who have resources related to the field of planning in charge of Conducting analysis and identification related to the development planning of either short number, medium-term or long-term development which will then be poured in the village's Medium term development plan (RPJMDes) as well as the interview results With the informant of JL said that in the planning of development must go through the process of analysis and identification, related to the analysis process and the identification is administratively-very in the notice, as administrative officials Of course identify and analyze administratively and then give consideration in conducting development planning[41].

Based on the information that researchers find in the field through interviews with various stakeholders in the field in conducting development planning in the villages Namlea, Lala, Karang Jaya, Siahoni, Batuboy, Marloso and Sanleko village do Analysis and identification of an activity that will be carried out in the framework of the development, but also some Parties that assume that the analysis and identification is only carried out normatively[42].

Fully realized that the development activities of the physical nature and related to the utilization of natural resources clearly contain the risk of changing the ecosystem that will further cause impact, both negative and positive. So this environment-based development planning must be continuous or sustainable by taking into account the environmental impacts that will occur later. Therefore, the development activities that should be implemented in addition to social and economic insight should also be environmentally sound, a project activity will affect environmental conditions and will cause impact on its environment, impact Created by the project activities can occur during the construction period and the project's operating period and can be a positive or negative impact for the environment. The interview with the chairman of the Community Empowerment Institute 
(LPM) of Namlea Village said that the village government of Namlea has not yet prioritized development based on the environment this proves with no in the input of the program Village forest reforestation in Namlea Village Government priority program and also the construction of village road that passes through the village Green Lane that pruning about 100 trees of village Perindang that until the time has not been done planting of the tree grinder. Similarly expressed by the head of the Village consultative Agency (BPD), which says that the environment-based development planning that was launched by the central government is still far from standard if it is reviewed from the concept of development planning Government in the village of Namlea subdistrict.

Based on the information above which researchers find in the field through interviews with various stakeholders in the field (village head, Village secretary, chairman of the Community Empowerment Institute, Chairman of the village consultative body as well as some Community who said that in planning development in Namlea district has not been fully based on the environment and the lack of coordination between institutions in the village to resolve the problem.

Development planning refers to the problem is how the development is not carried out at the same as the village government or reckless but is done based on the problems that exist in the village, the needs of the village and more specific to the needs of the community Which is found through aspiration and also based on human resources in Namlea subdistrict.

Based on the results of interviews that researchers do at the research site of various stakeholders who convey the opinion, whether the village head, the head of the BPD and the community said that the development planning in the District Namlea Refers to several things that exist in the village, the need for both general government needs and the needs of the community in particular, also very concerned about the aspirations or wishes conveyed by the village community Namlea, which Most importantly that the planning and implementation has been through coordination and deliberation between institutions located in each village[15].

According to Solekhan as an element of village governance, the village government has a duty to conduct governance, development, and societal affairs. Therefore, when viewed in terms of function, the village government has the function of: 1 ) conducting domestic affairs of the village, 2) implementing development and community building, 3) carrying out the construction of the village economy, 4) implementing construction Participation and self-government mutual assistance, 5) implement the Development of peace and Order of society, 6) conduct deliberation dispute resolution.

With regard to the duties and functions of each institution, the relationship between the head of village with BPD is partnership and is based on the principle of check and balances[43]. Therefore, the process of village governance should open a space for subtantive democracy, namely subtantive democracy that works on socio-cultural and political and institutional domains[44]. Thus, a partnership relationship between the village head and the BPD must rely on the belief, cooperation, and mutual respect aspects of the two, so that if the three aspects can be built together, it will be A harmonious partnership between the two.

The Data compiled based on discussions with the informant indicates the pattern of engagement of the village institutions divided into two parts. Marloso Village, Saihoni and Batuboy have a discussion room involving community leaders[45], religious figures and indigenous people in the formulation of implementation of Village fund management while Namlea village, Karang Jaya, Lala make formal spaces such as village meetings and Coordination of villages to involve community leaders and other village institutions in order to plan and supervise the use of village funds.

\section{Discussion}

The essence of development is the continuous process of change which is progress and improvement in the predetermined direction. "Development is a business or a series of business growth and planning changes that are made consciously by a nation, state and government to modernity in the framework of the nation's construction"[46]. Development is a process of change in the better direction through a planned effort.

In the course of planning and implementation of Village development, the village government is accompanied by the District government/city which is technically implemented by the device unit of district/city[47][48]. To coordinate Village development, village heads can be accompanied by professional escort personnel, village community Empowerment cadres, and/or third parties. Other designations will coordinate mentoring in the region. Village development includes the area of village governance, implementation of Village development, village community construction and Village Society empowerment[49].

For this, researchers interviewed GK informant who said that in a development planning there is generally must require analysis and identification that aims to parse the program that will be planned to fit Development needs in the village[50], therefore the village government spread in Namlea sub-district formed a special team consisting of village devices as well as community members who have resources related to the field of planning in charge of conducting analysis and identification related to the development planning of either short number, medium-term or long-term development which will then be poured in the village's Medium term development plan (RPJMDes) as well as the interview results With the informant of JL said that in the planning of development must go through the process of analysis and identification[51], related to the analysis process and the identification is administratively-very in the notice[52], as administrative officials of course identify and analyze administratively and then give consideration in conducting development planning.

\section{Conclusion}

Analysis and identification in the stages of development planning in the village in Namlea district has been done quite well, but not maximally but the engagement is a step forward in achieving community participation In general. The involvement of 
village institutions for the management of village funds allows for idea collaboration and resources so that at the stage of implementation of village funds can be generated target optimization. Villages with their effectiveness have their own ways to involve institutions in the framework of the utilization of village funds, some through formal spaces and also in the informal space.

\section{REFERENCES}

[1] R. I. Umasugi, C. C. Costa, M. Apriyanto, M. C. B. Umanailo, and N. Mufidah, "Dominance of Economic Capital in the Political," Int. J. Sci. Technol. Res., vol. 8, no. 9, 2019.

[2] H. Hamiru et al., "Eucalyptus Oil Workers," Int. J. Sci. Technol. Res., vol. 8, no. 9, 2019.

[3] R. Bugis et al., "Workers in the Namlea Market," Int. J. Sci. Technol. Res., vol. 8, no. 9, 2019.

[4] A. L. Wabula, M. Musyawir, A. Irmawati, B. Rebel, D. M. Darajat, and M. C. B. Umanailo, "Maghrib Movement," Int. J. Sci. Technol. Res., vol. 8, no. 9, 2019.

[5] A. Wael et al., “" Bupolo ' Motion Reading," Int. J. Sci. Technol. Res., vol. 8, no. 9, 2019.

[6] M. C. B. Umanailo, M. Yulisvestra, K. K. Oki, W. Mulyasari, and R. Ridwan, "The Thought of Emile Durkheim in the Contestation of Development in Indonesia," Int. J. Sci. Technol. Res., vol. 8, no. 8, 2019.

[7] S. S. F. Assagaf et al., "Construction of the Village as a Development Shaft in the Island Buru," Int. J. Sci. Technol. Res., vol. 8, no. 9, 2019.

[8] M. C. B. Umanailo et al., "Cybercrime Case as Impact Development of Communication Technology That Troubling Society," Int. J. Sci. Technol. Res., vol. 8, no. 9, 2019.

[9] W. Malmia et al., "Problem-Based Learning as an Effort to Improve Student Learning Outcomes," Int. J. Sci. Technol. Res., vol. 8, no. 9, 2019.

[10] B. Sam et al., "Female Feminism in the Customary Island of Buru," Int. J. Sci. Technol. Res., vol. 8, no. 8, 2019.

[11] R. Umanailo, M. Nawawi, M. C. B. Umanailo, S. Malik, and I. Hentihu, "Conversion of Farmland Namlea Subdistrict," Int. J. Sci. Technol. Res., vol. 8, no. 8, 2019.

[12] B. S. Amanto, M. C. B. Umanailo, R. S. Wulandari, T. Taufik, and S. Susiati, "Local Consumption Diversification," Int. J. Sci. Technol. Res., vol. 8, no. 8, 2019.

[13] M. C. B. Umanailo, "Overview Phenomenological Research,” pp. 1-6.

[14] L. J. Buton et al., "The Effect of Nasa Liquid Organic Fertilizer Concentration and Planting Distance to Growth and Production of Beans," Int. J. Sci. Technol. Res., vol. 8, no. 9, 2019.

[15] M. C. B. Umanailo, ILMU SOSIAL BUDAYA DASAR, 1st ed. Namlea: FAM PUBLISHING, 2015.

[16] M. C. B. Umanailo, "Kalesang Dorp in Context De Bouw van Village."

[17] A. Assagaf et al., "Educational Political Policy," Int. J. Sci. Technol. Res., vol. 8, no. 9, 2019.

[18] M. C. B. Umanailo, "Integration of Community Empowerment Models [Pengintegrasian Model Pemberdayaan Masyarakat]," Proceeding Community Dev., vol. 2, p. 268, Mar. 2019.

[19] M. C. B. Umanailo et al.," "Comprehension To Village," 2018, pp. 1-2.

[20] M. C. B. Umanailo, I. Hamid, M. Nawawi, S. Pulhehe, S. Yusuf, and A. T. Bon, "Utilization of Qualitative Methods in Research Universities," in Proceedings of the International Conference on Industrial Engineering and Operations Management, 2019, pp. $2076-2081$.

[21] M. Apriyanto and M. C. B. Umanailo, "Decrease Polyphenols, Ethanol, Lactic Acid , and Acetic Acid during Fermentation with Addition of Cocoa Beans Innoculum," Int. J. Sci. Technol. Res., vol. 8, no. 9, 2019.

[22] R. Djibu, I. Shofwan, and M. C. Basrun, "Development of Andragogical Learning Model to Improve Life Skill for Teenagers Who Drop Out of School in Gorontalo City," Int. J. Sci. Technol. Res., vol. 8, no. 10, 2019.

[23] M. Y. Zakaria, W. Malmia, A. Irmawati, N. F. Amir, and M. C. B. Umanailo, "Effect Mathematics Learning Achievement Motivation on Junior High School Students 1 Namlea," Int. J. Sci. Technol. Res., vol. 8, no. 10, 2019.

[24] M. S. J. Malisngorar et al., "Effect of Health Education Knowledge about Antenatal Care Mothers against Hamlet Land Shake the District Huamual West Seram Regency," Int. J. Sci. Technol. Res., vol. 8, no. 10, 2019.

[25] M. C. B. Umanailo, "Strategi Bertahan Hidup Petani Padi Gogo di Pulau Buru," J. Ekon. Pertan. dan Agribisnis, vol. 3, no. 1, pp. 50-58, Jan. 2019.

[26] M. Muhasidah et al., "Healthy Food with Children Learning Achievements at Makassar City Elementary School," Int. J. Sci. Technol. Res., vol. 8, no. 10, 2019.

[27] S. Prafitriyani, I. Magfirah, N. F. Amir, A. Irmawati, and M. C. B. Umanailo, "Influence of Emotional Intelligence on Mathematics Learning Outcomes of Class VII Middle School 9 Buru Students," Int. J. Sci. Technol. Res., vol. 8, no. 10, 2019.

[28] M. Jannah, R. Widohardhono, F. Fatimah, D. K. Dewi, and M. C. B. Umanailo, "Managing Cognitive Anxiety through Expressive Writing in StudentAthletes," Int. J. Sci. Technol. Res., vol. 8, no. 10, 2019.

[29] I. Shofwan et al., "Non-Formal Learning Strategy Based on Tahfidz and Character in the Primary School," Int. J. Sci. Technol. Res., vol. 8, no. 10, 2019.

[30] N. S. Wisnujati et al., "Public Relations Management through Management by Objective," Int. J. Sci. Technol. Res., vol. 8, no. 10, 2019.

[31] W. Rumaolat, E. Dusra, I. S. Tunny, M. S. J. Malisngorar, S. Cahyawati, and M. C. B. Umanailo, "Relationship Diet and Regulate Blood Sugar in the Elderly with DM Type li in Waimital Village , Kairatu District, West Seram Regency," Int. J. Sci. Technol. Res., vol. 8, no. 10, 2019.

[32] M. C. B. Umanailo, "Consumption Diversification of Local Community," J. AGRISEP Kaji. Masal. Sos. Ekon. Pertan. dan Agribisnis, vol. 18, no. 1, pp. 61-74, Mar. 2019.

[33] A. D. E et al., "The Existence of Waranggana in Tayub Ritual," Int. J. Sci. Technol. Res., vol. 8, no. 10, 2019.

[34] A. Rahmat, A. D. Gs, N. Djafri, I. Shofwan, and M. C. B. Umanailo, "The Influence of Family Leadership towards Adolescent Social Values in the City of Gorontalo," Int. J. Sci. Technol. Res., vol. 8, no. 10, 2019.

[35] A. Ervina, D. Zulmi, R. Ariesta, Y. Aridawarni, A. Aminah, and M. C. B. Umanailo, "The Relationship of Patterns Use of Time and Income Family with Juvenile Delinquency in Junior High School Students at Lebak Distric," Int. J. Sci. Technol. Res., vol. 8, no. 10, 2019.

[36] L. T. Muharlisiani et al., "The role of Customer Service through Customer Relationship Management ( CRM ) to Increase Customer Loyalty and Good Image," Int. J. Sci. Technol. Res., vol. 8, no. 10, 2019.

[37] M. Nawawi et al., "The Village Kalesang Program as a Poverty Alleviation Community," Int. J. Sci. Technol. Res., vol. 8, no. $10,2019$.

[38] M. C. B. Umanailo, MARGINALISASI BURUH TANI AKIBAT ALIH FUNGSI LAHAN, 1st ed. Namlea: FAM PUBLISHING, 2016.

[39] M. C. B. Umanailo and T. Yatno, Kajian dan Analisis Sosiologi Dalam Bentuk Kumpulan Essay, Makalah dan Opini. 2015.

[40] M. C. B. Umanailo, Sosiologi Hukum, 1st ed. Namlea: FAM PUBLISHING, 2016.

[41] M. C. B. Umanailo, MASYARAKAT BURU DALAM PERSPEKTIF KONTEMPORER, vol. 53, no. 9. 2015.

[42] M. C. B. Umanailo, R. Umanailo, R. Bugis, and A. T. Bon, "Empowerment Community in Buru Regency," in Proceedings of the International Conference on Industrial Engineering and Operations Management, 2019, pp. 2070-2075.

[43] A. Hasan Afandi and M. C. B. Umanailo, "Watudakon Citizens 'Social Conflict on Joker Toll Road Development in 2017 in Kesamben District, Jombang Regency," J. Soc. Sci. Res., vol. Special Is, no. 5, pp. 656-661, 2018.

[44] S. Yusuf, M. C. B. Umanailo, R. N. Putri, D. Qhuril, M. Ely, and D. Darma, "Village Institution Relations in the Utilization of Village Funds in Namlea 
District," Int. J. Sci. Technol. Res., vol. 8, no. 8, 2019.

[45] L. Rumkel, B. Sam, and M. C. B. Umanailo, "Village Head Partnership, Village Consultative Body and Customary Institution in Village Development," Int. J. Sci. Technol. Res., vol. 8, no. 8, pp. 1058-1063, 2019.

[46] M. C. B. Umanailo, "BUPOLO " Movement. 2019.

[47] S. Rachman, H. Hamiru, M. C. B. Umanailo, Y. Yulismayanti, and H. Harziko, "Semiotic Analysis of Indigenous Fashion in The Island of Buru," Int. J. Sci. Technol. Res., vol. 8, no. 8, pp. 1515-1519, 2019.

[48] M. C. B. Umanailo, M. Nawawi, and S. Pulhehe, "KONSUMSI MENUJU KONSTRUKSI MASYARAKAT KONSUMTIF," Simulacra, vol. 1, no. 2, pp. 203-211, 2018.

[49] M. C. B. Umanailo, "Studi pada Masyarakat Desa Waimangit Kabupaten Buru," SOCA, vol. 12, no. 12, pp. 63-74, 2018.

[50] M. C. B. Umanailo, "Discourse on the Consumerist Community Consumption," J. Soc. Sci. Res., vol. 5, no. 54, pp. 1181-1186, Apr. 2019.

[51] M. C. B. Umanailo, N. Handayani, A. Masniati, S. H. Makatita, and S. Lisaholit, "The Urbanization and Diversification of Farmland Namlea Village," Int. J. Sci. Technol. Res., vol. 8, no. 8, pp. 1049-1053, 2019.

[52] M. C. B. Umanailo, "Overview of Phenomenological Research," 2019, pp. 1-6. 